\title{
PENINGKATAN STATUS GIZI ANAK MELALUI PERBAIKAN POLA ASUH KELUARGA
}

\author{
$\operatorname{Agustina}^{1 *}$ \\ 1. Prodi S1 Keperawatan Fakultas Ilmu Kesehatan Universitas Pembangunan Nasional Veteran, Jakarta, Indonesia \\ *Email: tinaupn@yahoo.com
}

\begin{abstract}
Abstrak
Pola asuh keluarga merupakan salah satu faktor tidak langsung berhubungan dengan status gizi anak. Penelitian ini bertujuan mengetahui hubungan pola asuh keluarga dengan status gizi anak usia 6-59 bulan. Penelitian dilaksanakan di Kelurahan GL Depok dengan metode cross-sectional melibatkan 420 responden. Hasil analisis bivariat dengan uji Kai kuadrat menunjukkan hubungan signifikan antara pola asuh dengan status gizi $(p=0,00, \alpha=0,05)$ Puskesmas diharapkan dapat memberikan informasi kepada warga tentang pola asuh terhadap anak meliputi cara memilih, mengolah makanan, cara memberi makan pada anak, makanan pantangan bagi anak sehat, kebiasaan makan keluarga, ragam makanan, dan frekuensi makan dalam sehari dengan metode diskusi dan simulasi bagi ibu yang mempunyai anak usia 6-59 bulan.
\end{abstract}

Kata kunci: anak usia 6-59 bulan, pola asuh keluarga, status gizi anak.

\begin{abstract}
Family care pattern is an indirect factor affecting children nutritional status. The objective of this research was to identify the relationship between family care patterns with 6-59 months children nutritional status. It was conducted in Kelurahan GL Depok, applying cross-sectional methods involving 420 sample respondents. Bivariate analysis by chi-square test showed that there was a significant relationship between family care patterns with child nutritional status $(p=0,00, \alpha=0,05)$. This research suggested that the Puskesmas health care provider should increase the knowledge level of the lower educated mothers about the appropriate way of caring children especially in choosing, processing food, and feeding of varying foods, informing prohibited foods for children, family meal patterns, and everyday meal frequency for their children, by applying discussion and simulation techniques.
\end{abstract}

Key words: $6-59$ months old children, children nutritional status, family care pattern

\section{Pendahuluan}

Pembangunan kesehatan berupaya mewujudkan manusia sehat, cerdas, dan produktif agar dapat meneruskan pembangunan bangsa di masa datang. (Depkes RI, 2004). Salah satu kelompok yang penting diperhatikan dalam pembangunan tersebut adalah anak usia 6-59 bulan karena mereka akan berperan aktif dalam masyarakat dua atau tiga dekade mendatang. Usia bawah lima tahun disebut golden years dimana anak mengalami pertumbuhan dan perkembangan yang cepat sehingga memerlukan asupan gizi yang adekuat serta pola asuh yang baik.

Kekurangan gizi pada masa ini akan menghambat pertumbuhan jasmani dan perkembangan otak, serta mudah terkena infeksi. Secara lansung kekurangan gizi disebabkan asupan makan yang kurang dan penyakit infeksi, sedangkan faktor tidak langsung adalah pola asuh dan pengetahuan keluarga, dengan pola asuh yang baik dan perhatian orangtua terhadap asupan gizi anak dapat meningkatkan status gizi.

Herawati (2002) dalam penelitiannya mengatakan bahwa rendahnya konsumsi zat gizi memudahkan anak menderita infeksi, menyebabkan nafsu makan berkurang, absorbsi zat gizi terganggu, dan kehilangan nitrogen sangat besar. Hal ini dapat mengakibatkan Kekurangan Energi dan Protein (KEP). Pola asuh keluarga sangat penting diketahui oleh perawat, karena merupakan salah satu upaya promotif dan preventif dalam meningkatkan status gizi, pertumbuhan dan perkembangan anak. Perawat komunitas membantu individu dan keluarga agar terdorong untuk bertindak meningkatkan dan memelihara kesehatan keluarga. 
Perawat sebagai pendidik dalam bidang kesehatan dapat membimbing keluarga meningkatkan pengetahuan pengasuhan anak terutama menjaga asupan gizi yang dikonsumsi anak (cara memilih, mengolah, menyajikan makanan), merawat anak (memperhatikan asupan makanan yang beragam, frekuensi makan, mengenali tanda bahaya umum pada anak sepertitidak mau minum dan makan, anak enggan makan, anak memuntahkan makanan) dan mendidik anak tentang tata cara makan dan kebersihan diri.

Perawat dapat memberikan pendidikan kepada keluarga tentang perilaku makan anak pada setiap jenjang pertumbuhan yaitu umur satu (1) s/d 11 bulan, $12 \mathrm{~s} / \mathrm{d} 35$ bulan dan umur $36 \mathrm{~s} / \mathrm{d} 59$ bulan, sehingga keluarga dapat mengasuh anak dengan benar. Tujuan penelitian inimengetahui hubungan pola asuh keluarga dengan status gizi anak usia 6-59 bulan.

\section{Metode}

Penelitian ini menggunakan pendekatan kuantitatif dengan metode cross-sectional, dilakukan tahun 2007 di Kelurahan GL, wilayah Depok pada anak usia 659 bulan. Pengumpulan data dengan teknik wawancara berpedoman pada kuesioner, pengamatan, dan pengukuran.

Populasi sejumlah 1365 orang dengan total sampel 420 orang, dipilih berdasarkan systematic sampling. Data dikumpulkan oleh penulis dibantu enam mahasiswa S1 Keperawatan UPN 'Veteran' Jakarta. Analisis bivariat dengan Uji Kai kuadrat, Tingkat Kepercayaan 95\% dan Odds Ratio (OR) di mana nilai $\mathrm{p}<0,05$ menunjukkan hasil yang bermakna.

\section{Hasil}

\section{Gambaran Umum Daerah Penelitian}

Penelitian dilakukan di Kelurahan G, Depok, Jawa Barat. Luas Kelurahan G 450 hektar, dengan batasbatas: Kelurahan K di sebelah Utara, Kelurahan M di sebelah Selatan, Kelurahan M di sebelah Barat, dan Kelurahan TB di sebelah Timur. Jumlah penduduk hingga Mei 2007 sebanyak 13.183 jiwa, yakni 6.532 laki-laki dan 6.651 perempuan. Jumlah tempat tinggal
6019 rumah, $40 \%$ terdiri bangunan permanen, $60 \%$ semi permanen dan tidak permanen.

Sebagian besar penduduk adalah pemukim lama. Tingkat pendidikan penduduk 50\% SD, 25\% SLTP, 17\% SLTA, serta 8\% Diploma Tiga dan Sarjana. Sebagian besar penduduk bekerja di sektor yang tidak membutuhkan pendidikan tinggi seperti berjualan di pasar, karyawan tingkat rendah di kantor-kantor, buruh atau pekerja kasar, buruh-tani, dan sejenisnya. 15\% wilayah kelurahan adalah lahan pertanian ditanami padi, jagung, ketela pohon, ketela rambat, kedelai, sayur-sayuran, dan buah-buahan.

Sumber informasi seperti pemilikan televisi hanya 25\%, telepon rumah $15 \%$ dari jumlah keluarga. Sedangkan kepemilikan telepon seluler relatifmeluas dan merata di semua tingkatan pendidikan, pekerjaan, dan usia.

Pergaulan dan interaksi sosial cukup intensif, hubungan ketetanggaan cukup dekat, terlihat pada sore hari, banyak orangtua berkumpul di halaman rumah, bercakap-cakap seraya menyuapi anak-anak mereka. Banyak di antara keluarga yang bertetangga itu berkerabat satu sama lain. Sarana pelayanan kesehatan sangat kurang, hanya satu Puskesmas dengan dua dokter umum, lima perawat, dan dua bidan. Pelayanan Puskesmas sebagian besar dalam gedung sedangkan pelayanan luar gedung dirasakan kurang.

\section{Hubungan Usia dengan Status Gizi Anak}

Hasil analisis bivariat menunjukkan usia 6-11 bulan $(n=82), 69$ responden $(84,1 \%)$ berstatus gizi baik, dan 13 responden $(15,9 \%)$ berstatus gizi kurang. Usia $12-23$ bulan $(n=104), 84$ responden $(80,8 \%)$ berstatus gizi baik dan 20 responden $(19,2 \%)$ berstatus gizi kurang. Usia 24-36 bulan ( $n=125), 102$ responden $(80.8 \%)$ memiliki status gizi baik dan 23 responden $(18,4 \%)$ memiliki status gizi kurang. Usia $36-59$ bulan $(\mathrm{n}=109)$ berstatus gizi baik 72 responden $(66,1 \%)$ dan gizi kurang 37 responden $(33,7 \%)$.

Perhitungan statistik dengan uji Kai-kuadrat menghasilkan nilai continuity correction untuk nilai adalah 0,009. Ini menunjukkan bahwa ada hubungan bermakna antara umur dengan status gizi $(\mathrm{BB} / \mathrm{U})$. 


\section{Hubungan Pendidikan Orangtua Responden dengan Status Gizi Anak}

Hasil analisis menggambarkan dari 204 orangtua responden berpendidikan tinggi, 183 responden $(89,7 \%)$ status gizi baik, 21 responden $(10,3 \%)$ berstatus gizi kurang. Dari 216 orangtua responden berpendidikan rendah, 144 responden $(66,7 \%)$ mempunyai status gizi baik dan 72 responden $(33,3 \%)$ berstatus gizi kurang. Hasil uji Kai-kuadrat diperoleh ada hubungan signifikan tingkat pendidikan orangtua dengan status gizi $(p=0,00, \alpha=0,05)$. Nilai OR 4,35 $(2,55-7,42)$ sehingga dapat disimpulkan bahwa responden yang mempunyai orangtua berpendidikan tinggi berpeluang untuk status gizi baik 4,35 (95\%, CI 2,55-7,42) kali dibandingkan dengan orangtua berpendidikan rendah.

\section{Hubungan Penghasilan Per Kapita dengan Status Gizi Anak}

Hasil analisis dari 214 responden dengan penghasilan perkapita sama atau diatas Rp 335,000, menunjukkan 181 responden $(84,6 \%)$ berstatus gizi baik dan 33 responden $(15,4 \%)$ berstatus gizi kurang. Dari 206 responden penghasilan kurang dari Rp 335,000, 146 responden $(70,9 \%)$ berstatus gizi baik dan 60 responden $(29,1 \%)$ berstatus gizi kurang. Hasil uji Kai-kuadrat menunjukkan ada hubungan signifikan antara penghasilan per kapita dengan status gizi $(\mathrm{p}=$ $0,001, \alpha=0,05)$. Nilai OR 2,25 (1,39-3,63\%) menggambarkan keluarga berpenghasilan sama atau lebih dari Rp 335,000 berpeluang untuk status gizi baik 2,25 (95\% CI 1.39-3.63) kali dibandingkan dengan keluarga berpenghasilan kurang dari Rp 335.000.

\section{Hubungan Ragam Makanan yang Dikonsumsi Responden dengan Status Gizi Anak}

Hasil penelitian menunjukkan dari 312 responden mengkonsumsi makanan beragam, 276 responden $(88,5 \%)$ berstatus gizi baik dan 36 responden $(11,5 \%)$ berstatus gizi kurang. Dari 108 responden tidak mengkonsumsi makanan beragam, 51 responden $(47,2 \%)$ mempunyai status gizi baik, 57 responden $(52,8 \%)$ berstatus gizi kurang. Hasil uji Kaikuadrat didapatkan ada hubungan bermakna antara ragam makanan yang dikonsumsi responden dengan status gizi $(p=0,00, \alpha=0,05)$. Nilai OR $8.56(95 \%$ CI 5.12-14.31) menunjukkan responden mengkonsumsi makanan beragam mempunyai peluang status gizi baik 8,56 kali dibanding dengan responden yang tidak mengkonsumsi makanan beragam.

\section{Hubungan Frekuensi Makan Responden dengan Status Gizi Anak}

Hasil penelitian didapatkan dari 140 responden dengan frekuensi makan 3 kali sehari, 129 responden $(92,1 \%)$ berstatus gizi baik, 11 responden $(7,9 \%)$ status gizi kurang. Dari 220 responden dengan frekuensi makan 2 kali sehari 173 responden (78,6\%)status gizi baik dan 47 responden (21\%) berstatus gizi kurang. Dari 60 responden frekuensi makan 1 kali sehari 25 responden $(41,7 \%)$ mempunyai status gizi baik, dan 35 responden $(58,3 \%)$ ber status gizi kurang. Hasil uji Kai-kuadrat menunjukkan hubungan bermakna antara frekuensi makan responden dengan status gizi $(\mathrm{p}=$ $0,00, \alpha=0,05)$.

\section{Hubungan Pola Asuh Responden dengan Status Gizi Anak}

Hasil analisis menunjukkan dari 235 responden dengan pola asuh baik, 205 responden $(87,2 \%)$ mempunyai status gizi baik dan 30 responden(12,8\%) berstatus gizi kurang. Dari 185 responden dengan pola asuh tidak baik 122 responden $(65,9 \%)$ mempunyai status gizi baik dan 64 responden $(34,1 \%)$ status gizi kurang.

Hasil uji Kai-kuadrat didapatkan ada hubungan signifikan antara pola asuh dengan status gizi $(\mathrm{p}=0,00$, $\alpha=0,05)$. Nilai OR $3.52(95 \%$ CI, 2,16-5,75) artinya responden yang diberikan pola asuh baik berpeluang mempunyai status gizi baik 3,52 kali dibandingkan dengan responden yang tidak mendapatkan pola asuh baik.

\section{Hubungan Keadaan Kesehatan Responden sebelum Penelitian dengan Status Gizi Anak}

Hasil penelitian ditemukan dari 258 responden yang sehat dalam dua minggu sebelum penelitian. Dengan 240 responden (93\%) mempunyai status gizi baik, 
dan 18 responden (7\%) berstatus gizi kurang. Dari 162 responden yang sakit dalam dua minggu sebelum penelitian, 87 responden $(53,7 \%)$ berstatus gizi baik dan 75 responden $(46,3 \%)$ berstatus gizi kurang.

Hasil uji Kai-kuadrat menunjukkan ada hubungan bermakna antara keadaan kesehatan responden dengan status gizi $(p=0,00, \alpha=0,05)$. Nilai $O R=11.494(95 \%$ CI, 6.50-20.32) berarti responden yang sehat berpeluang status gizi baik 11,49 kali dibanding responden yang kondisi kesehatannya terganggu (sakit).

\section{Pembahasan}

\section{Hubungan Usia dengan Status Gizi Anak}

Asupan gizi yang adekuat sangat penting pada usia 659 bulan, yang digunakan untuk pertumbuhan berat badan, tinggi badan dan perkembangan otak serta perkembangan motorik halus dan kasar. Keluarga sebagai pengasuh perlu mengetahui tahapan perkembangan anak karena berbagai masalah akan ditemui seperti anak menolak makanan, dengan cara merapatkan bibirnya bila rasa makanan tidak disukai, menumpahkan makanan, atau tidak mau makan.

Semakin bertambah usia anak, pola makannya pun akan berubah, jenis makanan yang dapat dimakan anak juga semakin banyak, selain itu aktivitas fisik juga makin meningkat dan semakin beresiko mengalami gangguan gizi bila kebutuhan nutrisi tidak terpenuhi. Pengetahuan dan praktik pengasuhan tentang nutrisi yang dibutuhkan anak sangat penting diketahui keluarga agar anak dapat tumbuh dan berkembang sesuai dengan umur.

Keperawatan komunitas memberikan perhatian dalam peningkatan kesehatan dengan cara meningkatkan kemampuan keluarga, tentang stimulasi dan deteksi awal perkembangan anak, cara memilih bahan makanan, cara mengolah dan memberi makan, baik jumlah \& kualitas makanan yang dibutuhkan anak, ragam makanan dan keadaan kesehatan serta status gizi anak. Hasil analisis antara usia dan status gizi terbukti ada hubungan signifikan dengan $p=0,009$.

\section{Hubungan Tingkat Pendidikan Orangtua dengan Status Gizi Anak}

Tingkat pendidikan orangtua dapat memberikan gambaran mengenai pengetahuan, kemampuan, dan keterampilannya dalam mengasuh anak, semakin tinggi pendidikan orangtua semakin banyak informasi yang dapat diserap dari lingkungan, sehingga berpengaruh terhadap sikap dan perilaku serta gaya hidup sehari hari (Lembaga Ilmu Pengetahuan Indonesia, 2004).

Hasil penelitian didapatkan bahwa proporsi balita berstatus gizi kurang dengan sebanyak 33,3\% tingkat pendidikan orangtua rendah dan $10,3 \%$ berpendidikan tinggi. Secara statistik diperoleh hubungan bermakna antara tingkat pendidikan orangtua dengan status gizi anak. Hasil uji Kai-kuadrat menunjukkan hubungan signifikan dengan $\mathrm{p}=0,002$.

Perawat komunitas sebagai pendidik memberikan pelayanan promotif dan preventif dengan cara meningkatkan pengetahuan dan keterampilan keluarga dalam mempraktikkan pengasuhan anak yang tepat, sehingga asupan makanan yang diberikan dapat meningkatkan dan mempertahankan status gizi anak. Resiko terjadi gangguan gizi dapat dihindari, terutama bagi keluarga yang berpendidikan rendah, pendekatan yang digunakan dalam upaya promotif dan preventif adalah dengan menggunakan pendekatan proses keperawatan untuk dapat membantu keluarga membangun tujuan perubahan gaya hidup kearah yang sehat ( Maurer, Frances,A. Smith, Claudia.M,2005).

\section{Hubungan Penghasilan dengan Status Gizi Anak}

Salah satu faktor yang berperan pada status gizi adalah penghasilan keluarga, karena berhubungan dengan pengadaan makanan. Rata-rata penghasilan per kapita dalam penelitian ini Rp335.000,-. Presentase penghasilan lebih dari rata-rata $26,4 \%$, sedangkan di bawah rata-rata $73.6 \%$. Nilai ini berhubungan dengan ragam makanan dan frekuensi makan keluarga serta berpengaruh secara tidak langsung pada status gizi anak. Bila dibandingkan dengan Upah Minimum Regional(UMR) Depok tahun 2006 yaitu Rp890,000 perkapita, maka penghasilan di lokasi penelitian jauh dibawah UMR Depok. 
Rendahnya pendapatan menyebabkan orang tidak mampu membeli pangan dalam jumlah diperlukan. Hasil penelitian menunjukkan ada hubungan bermakna antara pendapatan per kapita dengan status gizi anak. Rendahnya pendapatan tersebut dapat dihubungkan dengan tingkat pendidikan, $42,1 \%$ ayah responden berpendidikan SMA dan SMP 21\%, serta SD 21,9\%. Begitu juga pekerjaan wiraswasta (berdagang sembako), buruh, dan tani. Uji statistik menunjukkan hubungan yang signifikan antara pendapatan perkapita dengan status gizi.

Penghasilan keluarga yang rendah merupakan salah satu faktor penyebab ketidak mampuan keluarga dalam mengadakan bahan makanan dalam jumlah yang dibutuhkan. Intervensi yang dapat diberikan oleh perawat komunitas untuk menunjang pemenuhan nutrisi anak terutama keluarga yang berpenghasilan rendah adalah dengan memberikan penyuluhan tentang makanan yang mengandung protein dan kalsium dengan harga terjangkau seperti, ikan teri, ceker ayam.buah sawo, srikaya, yang banyak terdapat dilokasi penelitian. Perawat komunitas dapat juga menyarankan agar keluarga dapat memanfaatkan pekarangan rumah untuk bertanam sayuran.seperti bayam, ,kacang kedelai, kacang panjang dan lain lain.

\section{Hubungan Pola Asuh dengan Status Gizi Anak}

Pola asuh merupakan salah satu faktor tidak langsung yang berpengaruh pada status gizi. Hal ini berhubungan dengan bentuk atau cara keluarga menjaga, merawat dan mendidik anak, yaitu bentuk atau tata cara keluarga dalam menjaga asupan nutrisi yang dikomsumsi anak (mulai dari memilih bahan makanan, mengolah dan menyajikan), merawat anak (memperhatikan: frekuensi makan, ragam makanan setiap hari, mengenali tanda bahaya umum pada anak seperti tidak mau minum\& makan, anak enggan makan serta anak memuntahkan makanan), dan mendidik anak (memahami perilaku anak tentang makan, dan merubah perilaku kearah hidup sehat, mendidik anak tentang cara makan dan kebersihan diri), sehingga tingkat kesehatan anak yang optimal dapat tercapai dan terhindar dari penyakit.

Keberhasilan proses pertumbuhan dan perkembangan anak tergantung dari keluarga mengasuh gizi anak.
Ukuran keberhasilan tersebut terlihat dari peningkatan status gizi anak yang diketahui dari peningkatan berat badan setiap bulan. Asupan gizi yang seimbang dan porsi yang tepat tidak hanya untuk peningkatan berat dan tinggi badan, tetapi juga untuk kecerdasan. Pengetahuan, kemampuan dan kemauan keluarga mengasuh anak terutama dalam memilih, mengolah, menyajikan dan memberi makan sesuai porsi yang dibutuhkan sangat diperlukan.

Perawat komunitas berperan meningkatkan kemampuan dan kemauan keluarga dalam mengasuh anak, terutama dalam memberi asupan nutrisi dengan menu seimbang dan porsi yang cukup, serta memantau status gizi dengan cara mengukur berat dan tinggi badan setiap bulan.

Penelitian menunjukkan bahwa 34,1\% responden umur 6-59 bulan termasuk dalam kategori pola asuh kurang baik. Berdasarkan analisis statistik ada hubungan signifikan dengan status gizi, $p=0,00$ dan $O R=3,52$. Dengan demikian dapat dikatakan semakin kurang baik pola asuh semakin besar kemungkinan anak menderita gizi kurang. Hasil penelitian ini mendukung hasil penelitian Harsiki (2003) di pedesaan dan perkotaan propinsi Sumatra Barat yang menemukan bahwa $57,1 \%$ anak bawah tiga tahun dengan pola pengasuhan kurang baik berdampak dengan keadaan gizi kurang. Hasil penelitian ini juga mendukung penelitian Widayani et al. (2001) bahwa pola asuh anak berpengaruh signifikan terhadap status gizi anak.

\section{Hubungan Ragam Makanan dan Frekuensi Makan dengan Status Gizi Anak}

Asupan makanan yang sehat tergantung dari porsi, frekuensi dan ragam makanan, yang dapat diperoleh dari hewan, sayur, atau buah yang di konsumsi setiap hari (Lembaga Ilmu Pengetahuan Indonesia, 2004). Status gizi baik dapat terpenuhi apabila asupan makanan yang dikonsumsi mengandung zat gizi seimbang antara jenis zat gizi yang dikonsumsi dengan banyak zat gizi yang dibutuhkan tubuh, seperti Karbohidrat, protein, lemak, mineral dan vitamin.

Masalah yang sering ditemui pada anak umur 6-59 bulan adalah sulit makan, anak tidak mau makan, 
atau enggan makan. Oleh sebab itu, variasi menu yang diberikan setiap hari perlu diperhatikan untuk mencegah kebosanan anak. Perubahan asupan makanan dan variasi menu yang diberikan akan mempengaruhi status gizi, rendahnya konsumsi energi dan protein atau tidak beragamnya makanan mengakibatkan terjadinya kekurangan Energi Protein. Bila masalah ini tidak ditangani secara serius maka kita akan kehilangan generasi penerus dimasa yang akan datang. Perhatian cukup dan pola asuh anak yang tepat akan memberi pengaruh yang besar dalam memperbaiki status gizinya.

Hasil analisis menunjukkan adanya hubungan yang bermakna ( $p=0,00, O R=8,5)$. Ini berarti anak yang mengkonsumsimakanan beragam mempunyaipeluang untuk mencapai status gizi baik sebanyak 8.56 kali dibandingkan dengan anak yang tidak mengkonsumsi makanan yang beragam.

Selanjutnya, Herawati (2002) mengatakan bahwa rendahnya konsumsi zat gizi memudahkan anak menderita infeksi, menyebabkan nafsu makan rendah, absorbsi zat gizi terganggu, dan kehilangan nitrogen sangat besar sehingga dapat menyebabkan atau memperberat Kekurangan Energi dan Protein(KEP). Selain itu, frekuensi makan perlu untuk memenuhi jumlah kalori yang dibutuhkan anak. Hasil uji statistik didapatkan $p=0,00$. Hal ini berarti ada hubungan yang bermakna antara frekuensi makan dengan status gizi.

Perawat komunitas berperan membantu keluarga agar terdorong untuk bertindak memelihara kesehatannya. Hal ini dapat dilakukan dengan cara meningkatkan pengetahuan dan keterampilan keluarga tentang menyusun menu untuk anak, memilih bahan makanan yang beragam dan frekuensi makan anak.

Salah satu upaya peningkatan pengetahuan dan keterampilan keluarga yaitu bekerjasama dengan keluarga dalam merencanakan dan mempraktikkan memilih bahan makanan yang bergizi, seperti sayur dan ikan yang segar. Selain itu, mempraktekkan cara mengolahnya, untuk selanjutnya melakukan pendampingan pada keluarga tentang cara memasak dan memberi makan anak.

\section{Hubungan Keadaan Kesehatan dalam Dua Minggu sebelum Penelitian dengan Status Gizi Anak}

Pertumbuhan dan perkembangan yang pesat pada anak usia 6-59 tahun menjadikan anak rentan terhadap gizi, apabila kebutuhan energi dan protein tidak terpenuhi daya tahan tubuh anak akan menurun. Sehingga mudah terserang penyakit, dan berakibat menurunnya berat badan dan kehilangan energi dalam tubuh.

Perawat komunitas sebagai pemberi pelayanan langsung keluarga dapat membantu keluarga dalam menilai tingkat kesehatan mereka, sehingga keluarga dapat mengetahui anak menderita infeksi, kecukupan asupan makanan, kebersihan perorangan maupun kebersihan lingkungan sekitar tempat anak berinteraksi dan beraktifitas.

Penyakit yang terbanyak diderita responden di lokasi penelitian dalam dua minggu sebelum penelitian adalah penyakit ISPA dan diare. Hasil penelitian juga menunjukkan bahwa $46,3 \%$ anak yang sakit mempunyai status gizi kurang, hal ini karena 38,6\% anak pernah sakit dalam dua minggu sebelum penelitian. Herawati (2002) mengemukakan ada hubungan timbal balik antara penyakit infeksi dengan status gizi. Seorang anak menderita infeksi akan mengalami penurunan nafsu makan, menolak makanan yang diberikan sehingga asupan zat gizi ke dalam tubuh menjadi berkurang. Hal ini menunjukkan adanya hubungan antara kondisi kesehatan dengan status gizi anak.

Periode dua tahun pertama kehidupan merupakan masa kritis bagi anak karena pada masa ini terjadi pertumbuhan dan perkembangan yang pesat, gangguan gizi pada masa ini dapat berakibat permanen karena tidak dapat dipulihkan walaupun kebutuhan gizi pada masa selanjutnya terpenuhi (Departemen Kesehatan, 2007).

Intervensi keperawatan yang dapat diberikan pada keluarga adalah meningkatkan pengetahuan dan keterampilan keluarga tentang tanda dan gejala anak sakit, pertolongan pertama pada anak yang menderita demam, asupan gizi dan cairan yang dibutuhkan. 
Perawat komunitas dapat memberikan pendidikan kesehatan dan pilihan-pilihan perawatan kesehatan yang dapat dilaksanakan keluarga, untuk mengatasi dan menghambat berlanjutnya proses penyakit dan pencegahan terjadinya gangguan gizi.

\section{Kesimpulan}

Sebagian besar keadaan gizi anak yang berusia 6-59 bulan di Kelurahan GL, Depok dengan menggunakan indikator berat badan menurut usia berstatus gizi baik dan sebagian kecil yang mengalami malnutrisi. Ada hubungan yang bermakna antara usia anak, pendidikan orangtua, penghasilan per kapita, pola asuh, ragam makanan, frekuensi makan, dan keadaan kesehatan anak dalam dua minggu sebelum penelitian dilaksanakan dengan status gizi anak usia 6-59 bulan.

Hasil penelitian menunjukkan proporsi tingkat pendidikan orangtua sebagian besar rendah, kemungkinan terjadi kekurangan gizi pada anak sangat tinggi, oleh sebab itu perlu mengembangkan pola asuh dengan pendekatan proses keperawatan untuk meningkatkan kesehatan dan pencegahan penyakit, sehingga tingkat kesehatan anak dapat optimal dan sumber daya yang akan datang lebih berkualitas. Pola asuh tersebut dapat dikembangkan oleh Perawat komunitas sebagai pendidik dan pemberi layanan keperawatan langsung kepada keluarga (Ekasari, Mia Fatma dkk 2002).

Adapun yang dimaksud pola asuh adalah bentuk atau tata cara keluarga dalam menjaga asupan nutrisi yang dikomsumsi anak (mulai dari memilih bahan makanan, mengolah dan menyajikan), merawat anak (memperhatikan: frekuensi makan, ragam makanan setiap hari, mengenali tanda bahaya umum pada anak seperti tidak mau minum\& makan, anak enggan makan serta memuntahkan makanan) dan mendidik anak (memahami perilaku anak tentang makan, dan merubah perilaku kearah hidup sehat, mendidik anak cara makan dan kebersihan diri) (LIPI, 2004).

Penelitian lebih lanjut dapat dilakukan dengan melakukan kombinasi metode kuantitatif dan metode kualitatif, dengan pendekatan proses keperawatan guna memperoleh pemahaman lebih mendalam mengenai hubungan pola asuh dengan status gizi (MD, JS, HH).

\section{Referensi}

Departemen Kesehatan RI. (2007). Keputusan Menteri Kesehatan N0. 747/Menkes/SK/VI/2007 tentang Pedoman Operasional keluarga Sadar Gizi di Desa Siaga, Jakarta. Jakarta: Balitbang Depkes.

Departemen Kesehatan RI. (2004). Sistem kesehatan nasional. Jakarta: Balitbang Depkes .

Ekasari, Fatma, M., et al. (2002). Keperawatan komunitas. Jakarta: Trans Info Media.

Harsiki, M.M.T. (2003). Hubungan pola asuh dan faktor lain dengan keadaan gizi anak batita keluarga miskin di pedesaan dan perkotaan Propinsi Sumatra Barat (Tesis, tidak dipublikasikan). Universitas Indonesia, Depok.

Herawati, T.H. (2002 ). Pengaruh pemberian makanan tambahan bagi balita KEP terhadap perubahan status gizi balita di Puskesmas Kabupaten Sidoarjo (Tesis, tidak dipublikasikan). Universitas Indonesia, Depok.

Lembaga Ilmu Pengetahuan Indonesia (LIPI). (2004). Ketahanan pangan dan gizi di era otonomi daerah dan globalisasi. Prosiding Widya Karya Nasional Pangan dan Gizi. Jakarta: LIPI.

Maurer, Frances, A., Smith, \& Claudia, M. (2005). Community/ puclic health nursing practice. Baltimore, MD: Elsevier Saunder.

Widayani, S., Hidayat, S., \& Kusharso, C. (2001). Hubungan antara pola asuh dengan status gizi anak batita pada rumah tangga petani di Kabupaten Bogor. Media Gizi dan Keluarga, Desember, XXV (2), 73-82.

Wong, D. (2004). Pedoman klinis perawatan pediatrik (Monica Ester, penerjemah). Jakarta: Penerbit ECG. . 